of the history of Ukraine of XIX - beginning XX cc.), (4), 84110. (in Ukr.)

17. Lazanska, T. I. (2009). Stanovysche bizhentsiv Ukrainy v roky Pershoi svitovoi vijny (O. P. Reient, Ed.). Problemy mstormn Ukranni XIX-pouatku XX st. (Problems of the history of Ukraine of XIX-beginning XX cc.), (16), 196-240. (in Ukr.)

\section{O. Reient}

\section{THE GREAT WAR 1914-1918 AS A GLOBAL UPHEAVAL AND OF ITS CONSEQUENCES FOR UKRAINE}

In the article, the World War First it examined from the perspective of a global cataclysm that essentially determined the further development of human civilization not only in the twentieth, but in also the early twenty-first century. It indicated that the tragedy of war especially manifested in the total character, which it has become, and the rapid fall in the value of human life. In its universal scope and demographic losses, this war greatly surpassed everything that happened thereto during the largest international military conflicts in human history.

It showed the influence of the global confrontation 19141918 on the Ukrainian ethnic lands, which were divided between the Russian Empire and Austria-Hungary. They have been the object of geopolitical encroachments of the warring parties and for four years become the theater of fierce fighting, and their population found itself on opposite sides of the front line.

Considerable attention it paid to elucidating the main "Ukrainian aspects» of the war in the political, ideological, military, economic and social planes. It shown both negative and positive consequences of the World War First for the formation of modern nation and the establishment of statehood.

Key words: World War First, the Great War, a global conflict, humanitarian catastrophe, politics, Ukraine.

УДК 94(477) «1917/1918»: 338.42](092)(045)

DOI: $10.31651 / 2413-8142-2018-19-8-14$

\section{А. І. Берестовий}

кандидат історичних наук, викладач суспільних дисциплін Черкаського художньо-технічного коледжу

Ю. Г. Пасічна

кандидат історичних наук, фахівець I категорії відділу аспірантури Черкаського національного університету імені Богдана Хмельнииького

\section{АГРАРНЕ ЗАКОНОДАВСТВО ЦЕНТРАЛЬНОЇ РАДИ: ВПЛИВ ПОЛІТИЧНОГО ЧИННИКА}

Статтю присвячено вивченню агарного законодавства Центральної Ради. На основі опрацьованих джерел та здобутків наукової літератури проаналізовано погляди і політичні переконання лідерів Центральної Ради на шляхи вирішення аграрного питання. Розкрито вплив політичного фактору на формування аграрного законодавства Центральної Ради

Ключові слова: Центральна Рада, аграрне законодавство, селянство.

Постановка проблеми. Сучасна Україна переживає період трансформацій у різних сферах

\footnotetext{
* Статтю написано згідно з держбюджетною темою «Українська революція (1917 - 1921 рр.): селянський фактор» (номер державної реєстрації 0118U003864)
}

життя. Однією з них є аграрна. Зміни в аграрній сфері $\epsilon$ відображенням тих процесів, що відбуваються в економіці та що пов'язані з формуванням сучасних ринкових відносин, виходом нашої держави на європейський ринок. Нові умови аграрного розвитку України не можливі без формулювання та врегулювання насамперед правового поля аграрної сфери. Тому звернення до вивчення досвіду історичного минулого, зокрема аграрного законодавства Центральної Ради, є актуальним. Його врахування дозволить, якщо не уникнути, то пом'якшити можливі негативні наслідки від сучасних реформ на селі.

Аналіз останніх досліджень і публікацій. Новітня вітчизняна історіографія з порушеної нами теми представлена напрацюваннями В. Верстюка [3], В. Солдатенка [31], О. Житкова [15], В. Капелюшного [18], Г. Корольова [23], Н. Ковальової [19], С. Корновенка [21] та інших. Водночас предметнішого вивчення потребує вплив політичного фактору на формування аграрного законодавства Центральної Ради.

Автори ставлять за мету дослідити погляди провідних представників Центральної Ради на вирішення аграрного питання та їх вплив на аграрне законодавство Центральної Ради.

Виклад основного матеріалу. Після Лютневої революції 1917 р. Центральна Рада стала органом влади в Україні. Ії діяльність розпочалася 4 березня 1917 р. і в перші місяці фокус їі уваги було зосереджено на вирішенні політичних та організаційних питань. Однак невдовзі діячі Центральної Ради на фоні загострення суспільно-політичної та соціальноекономічної ситуації зрозуміли необхідність вирішення аграрного питання та його правового врегулювання.

На початок 1917 р. селянство вже було активним суб' єктом суспільно-політичних процесів. Такий статус селянства був замовлений багаторічною бездіяльністю царського уряду. До того ж, вже в 1902 - 1907 рр. селянство стає повноправним учасником суспільно-політичних та соціальноекономічних трансформацій. Поділяємо думку С. Корновенка стосовно того, що дії селянства були віддзеркаленням бездіяльності уряду та «тупцюванням» на місці у вирішенні аграрного питання [22]. Невирішеність аграрного питання пояснюється об'єктивними та суб'єктивними причинами, які описані в історіографії. Звернемося до одного дослідження одного із малозв'ясованих політичного.

Законотворча діяльність із аграрного питання залежала від різних обставин, головна із них - партійна належність членів Центральної Ради. Українська Центральна Рада першого складу нараховувала 94 члени, другого (8 квітня 1917 р.) - 141, третього (8 серпня 1917 р.) - 655. До складу Центральної Ради входили представники 19 політичних партій, більшість iз яких - 17, були партіями соціалістичного спрямування: Українська соціал-демократична партія, Українська партія соціалістів-революціонерів, Українська партія соціалістів-федералістів тощо [27; 34].

Як зазначає В. Верстюк, значну увагу до аграрних проблем в Україні привернув кооперативний з'їзд Київщини, який проходив 14-15 березня 1917 р. [3]. 
3’їзд сколихнув не лише київські політичні кола, але й державу загалом. Він став відправною точкою для долучення різних політичних партій до вирішення аграрного складника Української революції. Кожна 3 них розробляла власну програму та пропонувала шляхи вирішення аграрного питання. Партії активно долучали до своєї діяльності селянство. Зважаючи на це, дії Центральної Ради перебували під пильним контролем політичних партій [29], на них впливала суспільно-політична активність селянства.

Приділення значної уваги вирішенню аграрного питання Центральною Радою пов'язано насамперед із політичними чинниками. До складу Центральної Ради було обрано 15 представників від Центрального комітету Селянської спілки та 133 представники від Всеукраїнської ради селянських депутатів [35]. Окрім того, на думку Т. Щетініної, давалося взнаки і те, що значна кількість представників Центральної Ради мала успішний досвід у кооперативному русі [39, 76].

Початком змін аграрного законодавства Центральної Ради вважають I Всеукраїнський селянський з'їзд, який проходив 28 травня - 2 червня 1917 р. у київському театрі Соловцова (нині - театр імені Івана Франка) [36, 4] під патронатом Центральної Ради. Масштабність і важливість з’їду була зрозумілою від перших днів засідання. На нього прибуло 2500 делегатів (1500 представників із правом голосу, решта - з дорадчим), які представляли інтереси Київщини, Поділля, Волині, Полтавщини, Чернігівщини, Катеринославщини, Харківщини, Таврії, Кубані та Донщини [36, 4]. Про серйозність намірів Центральної Ради у вирішенні аграрного питання красномовно свідчать слова М. Грушевського. У своєму виступі на відкритті з'їзду він сказав: «Ви знаєте, браття-селяни, що Українська Центральна Рада $€$ тією організацією, яку обрано представниками всього українського народу, аби організувати цей народ для спільної боротьби за землю і волю, за національно-політичні права всього народу. Центральна Рада, в склад якої входять і члени селянськоі спілки, піклується про економічний, національний i політичний добробут народу...» $[36,5]$. Аргументом на користь цієї нашої тези служить кількісний склад тих, хто записався до обговорення аграрного питання. Список нараховував 80 осіб, що представляли всі українські землі, на які поширювалася влада Центральної Ради [3].

Вагомим законодавчим підсумком I Bcepoсійського селянського з'їзду стала резолюція «Про землю» [36, 23]. Відповідно до ії змісту, скасовувалася приватна власність на землю; передбачалося формування земельного фонду, який повинен був підпорядковуватися Українському сейму; користування землею надавалося тим, хто буде ії обробляти «своїм руками»; зазначалася важливість встановлення трудової норми; усі витрати пов'язані 3 аграрними трансформаціями покладалися на державу; для справедливого вирішення аграрної проблеми передбачалося створення Центрального Українського земельного комітету; вирішення проблем iз переселенням оголошувалися пріоритетними; допускалася можливість створення гуртового ведення господарства через створення хліборобських товариств [36, 23-24].

Таким чином, завдяки суспільно-політичній активності селянства Центральна Рада зрозуміла необхідність вирішення аграрного питання. Перші місяці правління Центральної Ради показали, що селянство є рушієм змін в державі та тією силою, думку якої необхідно брати до уваги.

На третій сесії Центральної Ради, яка відбулася 7-9 травня 1917 р., позитивні відгуки знайшли слова Веселовського про необхідність вирішення аграрного питання та створення економічної ради, яка могла б працювати в цьому напрямі. Зволікання з вирішенням цього питання, на його думку, могло позбавити Центральну Раду підтримки з боку селянства $[35,83]$. Поки що вона їі мала. У доповідній записці Тимчасовому уряду від 30 травня 1917 р. було зазначено: «Селяни відносяться до Центральної Ради якнайкраще» $[35,129]$.

Всі українські партії розуміли необхідність реорганізації аграрного законодавства, хоча жодна партія на початок 1917 р. не мала чіткої програми 3 вирішення аграрного питання. Шляхи вирішення в кожної партії були свої. Наприклад, есери підтримували ідею соціалізації землі, тоді як есдеки виступали за їі націоналізацію та муніципалізацію.

Як уже зазначалося, більшість представників Центральної Ради були членами партій соціалістичного спрямування. Проаналізуємо головні програмні положення партії соціалістівреволюціонерів на початку 1917 р.: соціалізація приватновласницьких земель (вилучення землі із приватної власності); можлива передача земель у користування селянства без викупу; створення місцевих органів самоврядування для врегулювання відносин на місцях; проведення переселення за необхідності; конфіскація монастирських, кабінетських, удільних та державних земель для потреб селянства тощо [37].

Один із представників української партії соціалістів-революціонерів - М. Ковальський про програму своєї партії, стосовного вирішення аграрного питання, писав так: «Як позитивну програму аграрної перебудови України ми висували значну вже концепцію націоналізації землі, себто удержавлення всієї землі і створення земельного фонду української держави... ... за рахунок удержавлення великих панських маєтків буде збільшена площа селянського землеволодіння» [6].

М. Грушевський так висловлювався щодо позиції політичних партій, які вбачали вирішення аграрного питання шляхом соціалізації (Українська соціалдемократична партія, Українська партія соціалістівреволюціонерів, Українська партія соціалістівфедералістів): «Організації й партії українські стоять на тім, що земля повинна бути в руках тих, хто на ній працює. Землі казенні, удільні, монастирські і великі поміщицькі маєтки повинні бути забрані, а від поміщиків по справедливій оцінці їх коштів і прав маєтки треба викупити коштом українського крайового скарбу (казни) і роздавати в користування людям, які будуть на тій землі працювати. Український сейм обміркує, як сю справу перевести: скільки землі зоставити у теперішніх землевласників, яким способом відібрати від них лишки - за яким викупом, і як наділять потім людей землею з того земельного фонду» [12].

Цілком закономірно, що соціалістичні погляди відобразилися на програмних документах. Вже в I Універсалі Центральної Ради від 10 червня 1917 р. 
гучно заявлялося: «Народ український на своїй землі має право сам порядкувати життям» [1]. Передбачалося і видання законів, які б врегулювали проблеми конфіскації поміщицьких, казенних та монастирських земель «у власність народу» [1].

I Універсалом проголошувалося створення Генерального Секретаріату, який розпочав свою діяльність 15 червня 1917 р. У його складі діяло Генеральне секретарство земельних справ під керівництвом Б. Мартоса. Очільник відомства належав до Української соціал-демократичної робітничої партії. Однак, на його переконання, першочергове завдання, що стояло перед урядом, полягало в організації «елементів, що складали український національний рух як у Києві, так і по всій Україні, а також стимулювати його, де він був слабкий» [25]. На думку Б. Мартоса, складність становища селянства полягала також і в різноманітності аграрних програм різних політичних партій, кожна з яких включила пункт про наділення селян землею. Перші зусилля Генерального секретаріату оформилися в декларацію від 27 червня 1917 р. Однак неаграрною. Її швидше можна назвати організаційною. Нею проголошувалося створення волосних, повітових i губернських земельних комітетів та ради селянських депутатів, Крайового земельного комітету та кооперативних центрів, підготовка майбутнього земельного закону $[35,101]$.

Постає питання: чому ж Генеральний Секретаріат насамперед не ухвалював законів, спрямованих на вирішення аграрної проблеми? На думку В. Верстюка, Секретаріат просто не хотів вступати в суперечку із Тимчасовим урядом, який не ставив перед собою завдання вирішити аграрні проблеми держави, а покладав це на Установчі збори [3]. Вважаємо думку науковця доречною. Однак, хоча Тимчасовий уряд i ставив перед собою завдання вирішити аграрні проблеми селянства, все ж розумів важливість ii розв'язання та планував провести підготовчі заходи, що полегшили б роботу Установчих зборів. Міністерство землеробства на чолі з Міністром В. Черновим працювало над розробкою нових аграрних законопроектів. До роботи Міністерства землеробства долучився Головний земельний комітет та Ліга аграрних реформ. Тому, на нашу думку, Генеральний секретаріат теж міг працювати в цьому напрямі, до того ж I Універсалом це передбачалося. Такі дії Б. Мартоса в аграрному законодавстві пов'язуємо також, по-перше, із тим, що партія, до якої він належав, не мала власної аграрної програми; подруге, для вироблення аграрних законопроектів потрібен був час.

Літо- осінь 1917 р. увирішенні аграрного питання Центральною Радою можна охарактеризувати як період застою. До суперечки Центральної Ради 3 Тимчасовим урядом додалися проблеми легітимізації Генерального Секретаріату. До того ж загострилася ситуація на фронті, а суспільно-політична активність селянства посилилася. Селянство вимагало негайного вирішення аграрної проблеми. Центральна Рада зробила спробу працювати в цьому напрямі. Так, 9 липня 1917 р. було видано «Декларацію Генерального Секретаріату Центральної Ради». Одним із головних завдань проголошувалася розробка проекту земельного закону на підставі рішень Всеукраїнського селянського з'їзду [27]. Однак прихильності Тимчасового уряду ця Декларація не мала, тому вплинути суттєво на поліпшення ситуації не могла. Поділяємо погляди О. Воронянського стосовно того, що загострення відносин Центральної Ради з Тимчасовим урядом гальмувало прийняття необхідних законопроектів для вирішення аграрного питання [8].

Головою Центральної Ради було обрано М. Грушевського [4]. Стосовно вирішення аграрного питання він висловлювався так: «...справедливість: щоб трудящий чоловік мав усю користь від своєї праці, а не содержував своїм потом неробів усяких, що живляться 3 народної праці, самі не даючи ніякої користі народові» $[12,119]$. М. Грушевський розумів необхідність змін, однак зазначав, що для цього необхідно значні підготовчі заходи. Вирішення аграрного питання М. Грушевський покладав на Український сейм $[12,119]:$ «Щоб право на землю, проголошене нашим законодавством, могло бути здійснене справді: щоб кожний, кого тягне до праці, власної праці на землі, міг своє бажання справдити» [11]. Разом із тим він, як і керманичі Тимчасового уряду, зокрема міністри землеробства М. Шингарьов та В. Чернов, закликав до мирних дій селян. Висловлювався проти будь-якого самовільного захоплення землі та пошкодження майна. Однак першочерговим завданням Центральної Ради вважав автономію України, а вже після іiі встановлення вирішення всіх нагальних потреб, першість серед яких посідало аграрне $[12,119]$. Ці погляди не могли не позначитися на діяльності Центральної Ради. Другий універсал Центральної Ради від 3 липня 1917 р. лише побіжно згадував про необхідність аграрних змін [20]. За таку неуважність до аграрного питання та деякі інші позиції II Універсал в історіографії називають «стратегічною помилкою керівництва Центральної Ради на чолі з Грушевським» [28, 201].

Отже, діяльність Центральної Ради у вирішенні аграрного питання стала віддзеркаленням ії політичної структури. Кількісно в складі Центральної Ради на початок 1917 р. переважали партії соціалістичного спрямування. Окрім того, що політичні сили виявилися не готовими миттєво зреагувати на суспільнополітичну активність селянства (вони просто не мали чітких структуризовананих розроблених аграрних програм), ситуацію погіршували суперечки, які виникли між Центральною Радою та Тимчасовим урядом. До того ж, Центральна Рада не ставила вирішення аграрної проблеми першочерговим завданням. Влада була зосереджена на врегулюванні політичних протиріч.

Подія, що сталася 11-14 липня 1917 р., лише загострила ситуацію з вирішенням аграрного питання. На Всеукраїнському робітничому з'їді [10] дедалі посилилась відмінність поглядів есерів та есдеків щодо аграрного питання. Масла у вогонь підлив Б. Мартос. Він був доповідачем із земельного питання i висловився за вилучення землі із товарного обігу та, щоб іiї користування було «улаштоване в інтересах держави». Це суперечило тезі щодо передачі землі в користування тих, хто на ній працює, схваленій на I Всеукраїнському селянському з’їзді. Есдеки були прихильниками постанови I Всеукраїнського селянського з'зду.

Керівництво Генеральним Секретаріатом у найближчому майбутньому перейшли від 
В. Винниченка до Д. Дорошенка [39, 77]. Суспільнополітична активність селян улітку - восени 1917 р. посилилася. До Секретаріату земельних справ постійно надходили повідомлення стосовно суспільно-політичної активності селянства [16]. Д. Дорошенко підтримував діяльність Генерального Секретаріату, він вважав цей орган важливим у вирішенні різних проблеми України $[14,106]$. Як Д. Дорошенко, так і В. Винниченко розуміли гостроту селянських проблем та необхідність їх подолання. Д. Дорошенко зазначав, що селянство стало активнішим. Це відбувається через значну агітаторську політику різних сил та наповненням села солдатськими представниками, які закликали до активної дієвої боротьби [14, 141]. Д. Дорошенко вважав, що своїми діями як суспільство загалом, так і селянство зокрема «поклали край старим політичним порядкам» $[14,149]$, а тому Генеральний Секретаріат $\epsilon$ тим органом, який буде працювати в напрямі подолання проблем.

Д. Дорошенко був представником Української партії соціалістів-федералістів і поділяв її погляди. У своїх принципах аграрної політики партія прийняла резолюцію, яку розробив К. Мацієвич. Ії зміст містив такі положення: земля повинна належати державі; приватна власність скасована; аграрні перетворення повинні пройти шляхом демократизаціі землеволодіння; результатом демократизація мало бути примусове відібрання за певну платню всіх земель, які перевищували трудову норму для подальшого передання їх малоземельному і безземельному селянству [6].

В. Винниченко був одним із членів Української соціал-демократичної робітничої партії. Завершеної аграрної програми партія також не розробила. Однак висловлювалася за вилучення земель без викупу, була опонентом принципу соціалізації землі та пропагувала націоналізацію, вважала за необхідне встановлення споживчої та трудової норми, великі сподівання покладала на кооперацію [6].

В. Винниченко так описав село того часу: «Селянство, змучене війною, знервоване революцією, убоге в духовному житті, бідне на розвагу, на засоби одхилення психіки від тяжких явищ життя, кинулось в алкоголізм, шукаючи в йому здобуття й розваги. По всіх селах розплодилась в колосальній кількости саморобні гуральні, які курили горілку-самогонку. Сотні тисяч пудів винищувалось на вироб цієї п'яної отрути. Село напивалось, дуріло, труїлося, мучилося і рятувалося тою самою самогонкою...» [5, 50-51].

21 серпня 1917 р. головою Генерального Секретаріату став В. Винниченко. На цю посаду Петроградським урядом його було затверджено 1 вересня 1917 р. [24, 3]. Центральна Рада просто не могла більше ігнорувати становище в державі. Селянство вимагало негайних дій. Бездіяльність могла не просто призвести до загострення суспільнополітичного становища в Україні, а й стати причиною перевороту.

Квінтесенцією аграрного законодавства Центральної Ради став III Універсал від 8 листопада 1917 р. Він мав історичне значення для українського селянства. Вплив на положення Універсалу, що стосувалися аграрних трансформацій, мали М. ТуганБарановський та В. Мазуренко. Перший, який виступав за «соціальну волю» та вагому роль відводив сільськогосподарській кооперації, лише окреслив механізм аграрних змін, а погляди другого стали платформою дій $[17,148]$. Універсал проголошував: « ... існуюче право власності на землі поміщицькі та інші землі нетрудових хозяйств сільськогосподарстького значення, а також на удільні, монастирські, кабінетські та церковні землі, касується. Признаючи, що земля є власністю всього трудового народу і мають перейти до нього без викупу, Українська Центральна рада доручає генеральному секретаріату по земельних справах негайно виробити закон про те, як порядкувати земельним комітетом, обраним народом, тими землями до Українських Установчих зборів» $[35,400]$.

III Універсал Центральної Ради був революційним. Однак багато принципових моментів у ньому було обійдено мовчанкою. Наприклад, приватна власність на селянську землю, принципи соціалізації тощо. Відставка М. Мацієвича та М. Савченка-Більського стали поштовхом до розробки і оприлюднення пояснень до III Універсалу [3]. Розпорядженням Генерального Секретаріату було оголошено роз'яснення до Універсалу. По-перше, скасування приватної власності та передання іiі трудовому народу означало, що земля переходить до народу Української Народної Республіки; по-друге, після опублікування Універсалу заборонялися продаж, купівля, дарування та передача землі в будь-яку власність будь-кому; потретє, розміри земельних наділів, що не перевищували 50 дес. не підлягали конфіскації [27; 30, 112]. Насамкінець наголошувалося, що остаточне вирішення аграрного питання покладалося на Українські Установчі збори. У IV Універсалі Центральної Ради від 9 січня 1918 р. зазначалося про те, що уряд уже виробив необхідний закон передачі землі трудовому народу без викупу, в основу якого покладено скасування приватної власності та іï соціалізацію, а його прийняття відбудеться незабаром $[20 ; 2,97]$.

Законотворча активність Центральної Ради 3 аграрного питання завершилася прийняттям «Тимчасового земельного закону» 18 січня 1918 р. Він складався із трьох розділів: «Загальні засади», «Основні засади користування поверхнею землі», «Перехідні міри» та налічував 33 статті [38]. Він має неоднозначні оцінки науковців [9, 124; 32]. Авторами цього закону були П. Христюк та О. Шумський. «Тимчасовий земельний закон» вони розробляли, опираючися на проект фракції російських есерів у Другій Державній Думі [3].

Законом скасовувалася приватна власність на землю. Сільські громади, волосні, повітові й губернські земельні комітети отримали право власності в межах закону. Встановлювалася трудова норма - така кількість землі, яка б задовольняла споживчі потреби. Розмір трудової норми та термін її чинності визначали земельні комітети. У розпорядженні колишніх власників та орендарів залишалися ті землі, які вони могли обробити без найманої праці. Першочергове наділення землею стосувалося малоземельних i безземельних селян тощо [35, 128-131].

Заможні землевласники виступили за скасування цього закону [27], а малоземельне та безземельне селянство, хоча й направляло резолюції повітових селянських з'їздів стосовно його підтримки [16], та все ж 3 обережністю ставилося до дій уряду. Із цього 
приводу В. Винниченко зазначав: «Сільський пролетаріат в обіцянки і закони про землю не вірив, більше вірячи реальним фактам» $[5,309]$.

Із кінця січня до березня 1918 р. Центральна Рада не приймала ніяких агарних законопроектів, оскільки зовнішньополітична ситуація загострилася $[17,149$ 150]. 29 квітня 1918 р. Центральна Рада змінила розмір десятин, що не підлягали конфіскації, з 50 до 30 [13]. На думку О. Волошко, всі перипетії, пов'язані 3 III Універсалом, а також зменшення розміру десятини, які підлягали конфіскації, ще більше підірвали авторитет Центральної Ради серед селянства [7]. Однак впевнитися в позитивному результаті цієї поправки Центральна Рада так і не змогла. 29 квітня 1918 р. було проголошено «Грамоту до всього українського народу» П. Скоропадського [33, 463].

Висновки. Законодавчу діяльність Центральної Ради стосовно вирішення аграрного питання можна охарактеризувати як суперечливу. Подібно до Тимчасового уряду, Центральна Рада не ставила перед собою завдання вирішити аграрні проблеми села. Однак суспільно-політична активність селянства не просто привернула увагу Центральної Ради до цієі проблеми, а змусила владу зосередити свої зусилля на розробці різних законопроектів для урегулювання аграрних проблем. Одна 3 головних помилок політичних партій в осмисленні тогочасної аграрної ситуації полягала в тому, що вони вступили у 1917 p. iз застарілими аграрними проектами, що були прийняті ще у 1906-1907 рр. Лише із розгортанням селянських виступів навесні 1917 р. політики переглянули аграрні складники своїх програм. Політичні протиріччя різних політичних партій, які формували склад Центральної Ради, також стали однією із причин затримки вирішення аграрної проблеми.

\section{Список використаної літератури та джерел:} 1. ( I) УНІВЕРСАЛ УКРАЇНСЬКОЇ ЦЕНТРАЛЬНОЇ РАДИ до украӥнського народу, на Украӥні й по-за Украӥною сущого [Електронний ресурс]. - Режим доступу: http:// gska2.rada.gov.ua/site/const/universal-1.html

2. Бевз Т. Сочіально-економічні трансформаиї у добу Центральної Ради / Т. Бевз // Наукові записки Інституту політичних і етносочіальних досліджень ім. I. Ф. Кураса НАН України. - 2008. - Вип. 39. - C. 91-108.

3. Верстюк В. Земельне питання у стінах Центральної Ради / В. Верстюк [Електронний ресурс]. - Режим docmyny: http://www.inst-ukr.lviv.ua/files/23/580Verstiuk.pdf [in Ukr.]

4. Верстюк В. М. С. Грушевський у перший період діяльності Центральної Ради / В. Верстюк// Украӥнський історичний журнал. - 1996. - № 5. - C. 39-40.

5. Винниченко В. Відродження наиії: в 3 ч. / В. Винниченко. - К. ; Відень : Дзвін. - 1920. - Ч. II. 328 c.

6. Витанович I. Аграрна політика Украӥнськихурядів років револючї̈ й визвольних змагань (1917-20) / I Витанович [Електронний ресурс]. - Режим доступу: https:// docs.google.com viewer? url $=$ http $\% 3 A \% 2 F \% 2$ Fshron 1 . chtyvo.org.ua\%2FVytanovych Illia\%2FAhrarna polityka Ukrainskykh_uriadiv rokiv_revoliutsii_i_vyzvolnykh_zmahan_19171920.pdf [in Ukr.]

7. Волошко О. Актуальні проблеми досліджень історіі аграрних відносиндоби Українськоїреволюиії/О. Волочко // Вісник Харківського начіонального університету внутрішніх справ. - 2003. - Bun. 22.

8. Воронянський О. Економічна політика Центральноі Ради / О. Воронянський : автореф. ...кандидата історичних наук, Дніпропетровськ, 1995. - 14 c.

9. Гребенюк О. Спроби розв'язання Радою Народних
Міністрів Украӥнської Народної Республіки земельного питання у березні - квітні 1918 року / О. Гребенюк // Сіверянський літопис. - 2012. - № 3-4. - C. 123-128.

10. Гриченко А. Всеукраӥнський робітничий з '̈з д 1917 р. / А. Гриценко // Енциклопедія історії Украӥни: Т. 1: А-В / ред. В. А. Смолій. - К. : Наукова думка, 2003. $688 \mathrm{c}$.

11. Грушевський М. Твори : у $50 \mathrm{~m}$. / редкол. П. Сохань, Я. Дашкевич, I. Гирич [та ін.]. - Львів : Світ, 2002. - T. 4. -

Кн. I: Серія: Суспільно-політичні твори (доба Украӥнськоі Центральної Ради березень 1917 - квітень 1918). - 2007. $-248 c$.

12. Грушевський М. Хто такі украӥниі і чого вони хочуть / М. Грушевський. - К. : Знання, 1991.

13. Дюос Ф. Аграрне питання в документах Українськоі Центральної Ради (до 93-річчя з Дня утворення УЦР) / Ф. Джос [Електронний ресурс]. - Режим доступу: http:/ /www.rusnauka.com/5 PNW 2010/Istoria/ 59049.doc.htm 14. Дорошенко Д. Істороя Украӥни $1917-1923$ рр. : в 2 m. /упор. К. Ю. Галушко. - 2002. - T. 1. - К. : Темпора, 320 с. 15. Житков О. Соціально-правовий аналіз земельного законодавства Центральної Ради в новітній українській історіографії / О. Житков // Вісник Київського начіонального університету імені Тараса Шевченка. 2015. - №3(126). - C. 11-15.

16. Захарчук А. Права людини в контексті доктрини природного права періоду Украӥнської Народної Республіки й Украӥнської держави / А. Захарчук // Бюлетень Міністерства юстииії України. - 2011. - № 12. - С. 5-13. 17. Іващенко В. Еволючія нормативно-правової бази податкової політики Центральної Ради та Гетьманату в украӥнському селі (жовтень 1917 - грудень 1918 рр. )/ B. Іващенко, О. Тараненко. // Проблеми історії України XIX- початку XX cm. / НАН Украӥни. Інститут історіi України. - К. : Інститут історії Украӥни, 2010. - Випуск XVIII. - C. 149-150.

18. Капелюшний В. Начіональна еліта в Украӥнській революиї 1917 - 1921 років: інтерпретації вітчизняних та зарубіжних дослідників / В. Капелюшний, О. Коваль // Етнічна історія народів Свропи. - 2009. - Вип. 30.

19. Ковальова Н. Селяни, поміщики ідержава: конфлікти інтересів. «Аграрна революиія» в Україні 1902 - 1922 рр. / Н. Ковальова. - Д. : ЛІРА, 2016. - 368 с.

20. Конституиійні акти Украӥни. 1917-1920. Невідомі конститучії Украӥни. - Київ: Філософська і сочіологічна думка, 1992. - 272 с

21. Корновенко С. Селянин-бунтар. Селянська революиія в Украйні 1902 - 1917 рр. / С. Корновенко, О. Герасименко. - Черкаси: Чабаненко Ю. А., 2017. - 2014 c.

22. Корновенко С. Суб'єктний складник аграрного питання як одна з передумов Української революиіі 1917 - 1921 рр. / С. Корновенко // Украйнський історичний журнал. - 2017. - № 4. - С. 83-94.

23. Корольов Г. Академічний дискурс дослідження історії Украӥнської революиії 1917-1921 років (90-ті р. ХХ ст. початок XXI cm.) / Г. Корольов [Електронний ресурс]. Режим достуny: http://dspace.nbuv.gov.ua/bitstream/handle/ 123456789/40025/20-Korolev.pdf? sequence=1 [in Ukr.]

24. Кудлай А. Створення та діяльність народного міністерства земельних справ Украӥнської Народної Республіки (червень 1017 - кінеиь 1918 рр.) / А. Кудлай. -

К. : Поліграф. Дільниия Інституту історії України НАН Украӥни, 2011. - С. 3.

25. Мартос Б. Перші кроки Центральної Ради / Б. Мартос // Украӥнський історик. - 1973. - № 3-4.

26. Павленко Ю. Українська державність у 1917-1919 рр. (історико-генетичний аналіз) / Ю. Павленко, Ю. Храмов. - Київ, 1995. - С. 47.

27. Рогожин А. Земельне законодавство Центральної Ради / А. Рогожин, В. Гончаренко // Вісник Академії правових наук України. - 1997. - № 2.

28. Рубан А. М. С. Грушевський в роки Украӥнськоі револючії (1917-1918 рр. / А. Рубан // Наукові записки Наиіонального університету "Острозька академія». 2013. - Bun. 21. - C. 199-203.

29. Салата Г. Асиметрія інформації у виріменні земельного питання доби Центральної Ради УНР (1917 
- 1918 роки): історична ретроспектива / Г. Салата // Молодий учений. - 2016. - №12 (39). - C. 98-101.

30. Сидор В. Історико-правові передумови формування вітчизняного земельного законодавства / В. Сидор // Вісник Запорізького начіонального університету. Серія: Юридичні науки. - 2010. - № 4. - C. 112.

31. Солдатенко В. Стан історіографічної розробки та актуальні проблеми дослідження історії Українськоі революиії / В. Солдатенко // Украӥнський історичний журнал. - 1999. - № 1. - С. 68-85.

32. Терещенко Ю. Сочіально-економічна політика урядіє УНР доби Центральної Ради / Ю. Терещенко // Студії з історії Українськоїреволючії 1917-1921 років: на пошану Руслана Яковича Пирога. - К. : Інститут історії Украӥни НАН України, 2011. - С. 21-36.

33. Терлюк I. Аграрне питання як фактор правової політики українських державних формаиій (1917-1921 рр.): започаткування начіонального земельного законодавства / I. Терлюк // Вісник Національного університету «Львівська політехніка». - Львів, 2016. - № 850. - C. 461-468.

34. Трикіма А. Аграрне питання в діяльності Українськоі партії соиіалістів-федералістів у добу Українськоі революиії 1917-1920 рр. / А. Трикіша [Електронний pесурс]. - Режсим доступy: http://enpuir.npu.edu.ua/handle/ $123456789 / 13906$

35. Українська Центральна Радам: документи $i$ матеріали : у 2 m. / упор. В. Верстюк [та ін.]. - К. : Наукова думка, 1996. - Т. 1. - 588 с

36. Хміль I. Перший Всеукраӥнський селянський з 'ізд / I. Хміль. - К., 1992. - № 2.

37. ЦДІАК України, ф. 1435, on. 1, спр. 9; ЦДІАК Украӥни ф. 1435, оп. 1, спр. 6; ЦДІАК Украӥни, ф. 385, оn. 1, спр. 1762; ЦДІАК Украӥни, ф. 386, on. 1, сnр. 574.

38. Центральний державний архів вищих органів влади та управління Украӥни, ф. 1115, оп. 1, спр. 1. Тимчасовий земельний закон УНР, 185-187 арк.

39. Щетініна Т. Становлення державного управління в аграрній сфері за доби Української Центральної Ради (1917 - 1918) / Т. Щетініна // Науковий вісник Херсонського державного університету. - 2014. - T. 1 .

\section{References:}

1. (I) IN THE EVENT OF THE UKRAINIAN CENTRAL COUNCIL to the Ukrainian people, in Ukraine and in Ukraine. Retrieved from http://gska2.rada.gov.ua/site/const/universal1.html [in Ukr.]

2. Bevz, T. Socio-economic transformations in the era of the Central Rada. Scientific notes of the Institute of Political and Ethno-Social Studies. IF Kuras, National Academy of Sciences of Ukraine. 39, 91-108. [in Ukr.]

3. Verstyuk B. Land Issues in the Rivers of the Central Rada from http://www.inst-ukr.lviv.ua/files/23/580Verstiuk.pdf

4. Vestyuk, V. (1996). M. S. Hrushevsky in the first period of the Central Rada's activity. Ukrainian Historical Magazine. 5 , 39-40. [in Ukr.]

5. Vynnychenko, V. (1920). Vidrodzhennia natsii. (Vols. 1-3). K. ; Viden : Dzvin. [in Ukr.]

6. Vitanovich, I. Agrarian Policy of Ukrainian Governments during the Revolution and Liberation Contest (1917-20). Retrieved from https://docs.google.com/viewer?url= http $\% 3 \mathrm{~A} \% 2 \mathrm{~F} \% 2 \mathrm{Fshron} 1$.chtyvo.org.ua\% $\%$ FVytanovych Illia\% $\% 2 \mathrm{~F}$ Ahrarna polityka_Ukrainskykh_uriadiv_rokiv revoliutsii i_v yzvolnykh zmahä 1917-1920.pdf [in Ukr.]

7. Voloshko, O. (2003). Topical Problems of Research in the History of Agrarian Relations of the Age of the Ukrainian Revolution. Bulletin of the Kharkiv National University of Internal Affairs. 22. [in Ukr.]

8. Voronyansky, O. (1995). Central Policy Economic Policy. Abstract of candi-date's thesis. Dnipropetrovsk. [in Ukr.]

9. Grebenyuk, O. (2012) Attempts to be resolved by the Council of People's Ministers of the Ukrainian People's Land Issues in March - April 1918. The Siverian Chronicle. 3-4, 123-128. [in Ukr.]
10. Gritsenko, A. (2003). All-Ukrainian Workers' Congress of 1917. Encyclopedia of Ukrainian History. V. A. Smolij (Ed.). K. : Scientific thought. [in Ukr.]

11. Grushevskii, M. (2007). Works. (Vols. 1-50. P. Sokhan, Y. Dashkevich, I. Girich. (Eds.). Lviv : World. [in Ukr.]

12. Hrushevsky, M. (1991). Who are Ukrainians and what they want. K. : Knowledge [in Ukr.]

13. Josh, F. Agrarian question in the documents of the Ukrainian Central Rada (to the 93rd anniversary of the UCR) Retrieved from http://www.rusnauka.com/5_PNW_2010/Istoria/ 59049.doc.htm. [in Ukr.]

14. Doroshenko, D. (2002). History of Ukraine $1917-1923$. (Vols. 1-2). K. Yu. Galushko (Ed.).- K.: Tempora. [in Ukr.]

15. Zhitkov, O. (2015). Social-legal analysis of the land legislation of the Central Council in the newest Ukrainian historiography. Bulletin of the Taras Shevchenko National Taras Shevchenko University. 3(126), 11-15. [in Ukr.]

16. Zakharchuk, A. (2011). Human rights in the context of the doctrine of the natural law of the period of the Ukrainian People's Republic and the Ukrainian state. Bulletin of the Ministry of Justice of Ukraine. 12, 5-13. [in Ukr.]

17. Ivashchenko, V. \& Taranenko O. (2010). Evolution of the normative and legal base of tax policy of the Central Rada and Hetmanate in the Ukrainian village (October 1917 - December 1918). Problems of the History of Ukraine of the XIX - early XX centuries. K. : Institute of History of Ukraine. XVIII. (p. 148.). [in Ukr.]

18. Hatchetney, V. \& Koval, O. (2009). National elite in the Ukrainian Revolution of 1917-1921: interpretations of domestic and foreign researchers. Ethnic History of the Nations of Europe. 30. [in Ukr.]

19. Kovaleva, N. (2016). Peasants, landowners and state: conflicts of interest. "Agrarian Revolution" in Ukraine 1902 1922. D.: LIRA. [in Ukr.]

20. Constitutional Acts of Ukraine. 1917-1920. Unknown to the constitution of Ukraine. (1992). Kyiv: Philosophical and Sociological Thought. [in Ukr.]

21. Kornovenko, S. \& Gerasimenko, O. (2017). Rebel peasant. Peasant Revolution in Ukraine 1902 - 1917 years. Cherkasy: Chbanenko Yu.A., [in Ukr.]

22. Kornovenko, S. (2017). The Subjective Component of the Agrarian Question as One of the Preconditions of the Ukrainian Revolution of 1917 - 1921. Ukrainian Historical Magazine. 4, 83-94. [in Ukr.]

23. Korolov, G. Academic Discourse on the Study of the History of the Ukrainian Revolution of 1917-1921 (90s of the 20th Century - the beginning of the 21 st Century). from http:// dspace.nbuv.gov.ua/bitstream/handle/123456789/40025/20Korolev.pdf?sequence $=1$ [in Ukr.]

24. Kudlay, A. (2011). Creation and activity of the People's Ministry of Land Affairs of the Ukrainian People's Republic (June 1017 - the end of 1918). K. : Polygraph. Section of the Institute of History of Ukraine of the National Academy of Sciences of Ukraine. [in Ukr.]

25. Martos, B. The First Steps of the Central Council (1973). Ukrainian Historian. 3-4. [in Ukr.]

26. Pavlenko, Y. \& Khramov, Yu. (1995). Ukrainian statehood in 1917-1919 (historical and genetic analysis). Kyiv, (p. 47.) [in Ukr.]

27. Rogozhin, A. \& Goncharenko, V. (1997). Land legislation of the Central Rada. Bulletin of the Academy of Legal Sciences of Ukraine. 2. [in Ukr.]

28. Ruban, A. (2013). M. Hrushevsky during the Ukrainian Revolution (1917-1918). Scientific Notes of the National University of Ostroh Academy. 21, 199-203. [in Ukr.]

29. Salata, G. (2016). Asymmetry of information in solving the land issue of the Central Council of the UPR (1917-1918): a historical retrospective. Young scientist. 12(39), 98-101. [in Ukr.]

30. Sidor, V. (2010). Historical and legal preconditions for the formation of domestic land legislation. Bulletin of the Zaporizhzhya National University. Series: Law Sciences. 4., p. 112. [in Ukr.]

31. Soldatenko, V. (1999). The Structure of Historiographical Development and Actual Problems in the Study of the History 
of the Ukrainian Revolution. Ukrainian Historical Magazine. 1, 68-85. [in Ukr.]

32. Tereshchenko, Y. (2011). Social-economic policy of the governments of the UNR of the Central Rada. Studios on the history of the Ukrainian revolution of 1917-1921: in the honor of Ruslan Yakovlevich Pirog.K.: Institute of History of Ukraine of the National Academy of Sciences of Ukraine. [in Ukr.] 33. Terlyuk, I. (2016). The agrarian question as a factor of the legal policy of Ukrainian state formations (1917-1921): the introduction of national land legislation. Bulletin of the National University "Lviv Polytechnic". Lviv. 850, 461-468. [in Ukr.] 34. Tricisha, A. The agrarian question in the activity of the Ukrainian party of socialist-federalists during the period of the Ukrainian revolution of 1917-1920. Retrieved from http:/ /enpuir.npu.edu.ua/handle/123456789/13906 [in Ukr.]

35. Ukrainian Central Rada: documents and materials. (1996). (Vols. 1-2). (Em. V. Verstyuk). - K. : Scientific thought. [in Ukr.]

36. Khmil, I. (1992). Pershyi Vseukrainskyi selianskyi zizd. K., 2. (p. 2). [in Ukr.]

37. TsDIAK Ukrainy, f. 1435, op. 1, spr. 9; TsDIAK Ukrainy, f. 1435 , op. 1, spr. 6; TsDIAK Ukrainy, f. 385 , op. 1 , spr 1762; TsDIAK Ukrainy, f. 386, op. 1, spr. 574.

38. Central State Archive of the Supreme Power and Administration of Ukraine, f. 1115, op. 1, spr. 1. Provisional land law of the UPR, 185-187 ark.

39. Shchetynina, T. (2014). The formation of public administration in the agrarian sector during the time of the Ukrainian Central Rada (1917-1918). Scientific Bulletin of the Kherson State University. 1, p. 76. [in Ukr.]

\section{A. Berestoviy, Y. Pasichna}

\section{AGRICULTURAL LEGISLATION OF THE CENTRAL COUNCIL: INFLUENCE OF POLITICALFACTOR}

The brief period of the Ukrainian Revolution of 1917 1921 was extremely rich in events that influenced all spheres of life of the society. Today, the Ukrainian revolution is viewed as a socio-cultural, multidimensional phenomenon that affected the process of national construction of the Ukrainian state.

The authors aims to explore the views of the leading representatives of the Tsentralna Rada (the Central Council) on the solution of the agrarian Issue and also their influence on the agrarian legislation of the Tsentralna Rada.

Aggravation of the agrarian issue in the spring - autumn of 1917 was a consequence of many years of ill-conceived agrarian policy of the royal power. Peasants perceived the revolution as an end to the old land regime and were confident that the government will soon begin to address the agrarian issue. However, this issue remained unresolved, which caused socio-political activity of the peasantry.

The Tsentralna Rada had all the information on the sociopolitical, social and economic situation in the state. However it was delaying the decision of the agrarian issue. There are many scientific studies in the world and native historiography on objective and subjective reasons that interfered with the solution of the agrarian issue. One of the subjective reasons, in our opinion, was personality factor.

Socialization, nationalization, municipalization, establishment of labor and consumer norms, "minimum" and "maximum" measures, alienation of land and leaving it with its previous owners, free and paid alienation of land, allowing land to be on local self-government, communities and states disposal - this is just a short list of the main agrarian provisions of political parties. Political parties criticized the agrarian programs of their opponents and proved relevance of their own programs. The versatility of the agrarian regulations of various political parties and their inability to find a common solution has become a barrier to the development of the agrarian legislative platform of the Tsentralna Rada.

Key words: Central Council, agrarian law, peasantry.
УДК 94(477): 943

DOI: $10.31651 / 2413-8142-2018-19-14-18$

О. А. Бундак

кандидат історичних наук, дочент, заступник директора з науково-методичної роботи Луцького інституту розвитку людини Університету «Украӥна»

\section{ІНТЕГРАЦІЯ УКРАЇНСЬКОГО СЕЛЯНСТВА ПРИКОРДОННИХ ТЕРИТОРІЙУ ГРОМАДСЬКІ ОРГАНІЗАЦІї (СПІЛКИ, ОБ’ЄДНАННЯ)}

У статті вивчено прочесс зростання політичноі свідомості украӥнського селянства, у контексті сочіально-економічних $i$ політичних подій та безпосередньої участі в них селянства в першій половині ХХ ст. Підкреслено, шуо ией процес виявився у створенні різнопланових організачій, об'єднань та спілок, де, поряд із економічними вимогами, ставилися $і$ політичні, боротьбі різних партій $і$ організаиій за селянство. Закцентовано увагу на формах вияву участі селянства у суспільно-політичному житті держави; створенні власних організацій або приєднанні до уже існуючих.

Ключові слова: політизація, селянство, політична організачія, політична партія, форми протесту, спілки, Союзи, свідомість, менталітет.

Постановка проблеми. В останні десятиліття селянськознавча тема стала тим науковим напрямом, який переживає своєрідний ренесанс в новітній українській історіографії. Аграрне питання, шляхи і темпи модернізації українського села, участь селян у військових подіях, організаціях та об'єднаннях в першій половині XX ст. - ось неповний перелік тематичних лакун, які особливо помітні в сучасних історикополітичних дослідженнях. Це зумовлює пильний інтерес дослідників до зростання політичної свідомості селянства та його посильній участі в утворенні та діяльності різнопланових організацій, до набуття практичного досвіду політичної діяльності.

У запропонованій науковій розвідці ми ставимо за мету розглянути політизацію українського селянства, яка реалізовувалася в практичній площині шляхом створення та його участі в різнопланових об'єднаннях.

Актуальність запропонованої теми зумовлена активною участю селянства у політичних процесах першої половини XX століття; відсутністю грунтовних досліджень щодо участі селян в організаціях, спілках, союзах на прикордонних територіях.

Аналіз останніх досліджень і публікацій. Окремі питання, співзвучні 3 нашою темою, знайшли висвітлення у науковій літературі $[1 ; 2 ; 3 ; 4 ; 5]$. Окремі селянські політичні цінності, настанови і стандарти вивчено у працях В. Марочка, С. Корновенка [6; 7]. Аналіз ментальних характеристик селянства в контексті конкретної історичної епохи представлено у роботах Ю. Присяжнюка, О. Михайлюка, В. Лозового [8; 9; 10].

Виклад основного матеріалу. Історія українського селянства - тема, що постійно перебувала i продовжує перебувати у фокусі наукової уваги. Вивчення основних аспектів життя і діяльності українського селянства початку XX ст. у всіх його проявах - одне з наріжних завдань сучасної української історіографії, неодноразово підкреслював О.Реєнт [11, 225]. Селянство лишалося домінуючою соціальною групою, хоча його значна частина була 